\title{
STRATEGI PENGAWAS SEKOLAH DALAM MEMBANTU GURU MENGATASI KESULITAN BELAJAR GEOGRAFI DI SMA SWASTA KESUMA INDAH T.P. 2017/2018
}

\author{
Oleh : \\ MAHDALENA \\ Email: ml4801589@gmail.com
}

\begin{abstract}
Dalam proses pembelajaran ada kalanya siswa mengalami kesulitan belajar. Kesulitan-kesulitan belajar tersebut berpengaruh terhadap hasil belajar yang diperoleh siswa, sehingga perlu dilakukan langkahlangkah untuk mengatasi permasalahan tersebut. Salah satu upaya yang dilakukan adalah melakukan penelitian tindakan dan menerapkan strategi yang tepat.

Kesulitan belajar yang dilami siswa pada mata pelajaran Geografi di Kelas XI SMA Swasta Kesuma Indah di antaranya proses belajar yang dilakukan siswa tidak berfungsi dengan baik, siswa yang sesungguhnya memiliki tingkat potensi intelektual yang tergolong di atas normal, tetapi prestasi belajarnya tergolong rendah. Strategi yang dilakukan di antaranya melakukan identifikasi kasus kesulitan belajar, menandai siswa yang mengalami kesulitan belajar, mealakukan lokalisasi jenis dan sifat kesulitan, berusaha menemukan faktor penyebab kesulitan belajar yang dihadapi siswa, meneliti hasil ulangan dan membandingkannya dengan nilai rata-rata kelas, melakukan obsservasi terhadap prilaku belajar siswa, merencanakan alternatif penyembuhan dan melaksanakan penyembuhan. Masalah-masalah yang yang dihadapi guru dalam mengatasi kesulitan belajar siswa adalah masalah yang berasal dari dalam diri siswa, seperti siswa sulit diatur dan masalah dari luar diri siswa kurangnya peran aktif orangtua. Upaya yang dilakukan untuk menanggulangi masalah tersebut adalah melakukan pendekatan individual, memberikan remedial kepada siswa, berusaha memanfaatkan fasilitas yang ada secara optimal, dan menjalin komunikasi dengan orangtua untuk membantu mengatasi kesulitan belajar siswa.
\end{abstract}

Kata Kunci: Strategi, Pengawas Sekolah, Guru, Kesulitan Belajar, Siswa

\section{PENDAHULUAN}

Perkembangan pengetahuan dan teknologi menuntut profesionalisme guru dalam siswa mengalami kesulitan belajar pada mata melaksanakan tugas dan fungsinya sebagai pelajaran Geografi. Hal ini antara lain tampak pendidik, pengajar dan pelatih bagi para kurangnya minat dan motivasi belajar, perhatian siswanya. Untuk meningkatkan keberhasilan dan konsentrasi belajar, serta rendahnya pendidikan dan pengajaran di sekolah, antara lain perolehan nilai rata-rata ulangan harian yang guru harus mampu menerapkan strategi yang diperoleh siswa, yaitu 68, sedangkan Kriteria tepat dalam membantu siswa mengatasi kesulitan Ketuntasan Minimal yang ditetapkan adalah 75 . belajar yang dihadapinya agar hasil belajar siswa Karena itu perlu dilakukan penelitian apakah dapat ditingkatkan.

Berbagai upaya dilakukan oleh guru untuk mengatasi kesulitan belajar siswa, yaitu melalui pendekatan individual, mencari sebabsebab kesulitan belajar siswa, menggunakan metode mengajar yang bervariasi, dan anak yang mengalami kesulitan belajar. Misalnya mengusahakan perbaikan prilaku belajar siswa. siswa lambat memahami materi pelajaran yang Namun ada kalanya guru mata pelajaran meminta disampaikan guru, dan siswa menghindari belajar bantuan Pengawas Sekolah untuk menanggulangi dengan cara membolos ketika kegiatan belajar kesulitan belajar yang dialami siswa. Hal ini mengajar sedang berlangsung. Kondisi ini antara lain tampak dalam pembelajaran Geografi menimbulkan pertanyaan apakah kesulitan di SMA Swasta Kesuma Indah T.P. 2017/2018.

belajar tersebut disebabkan penerapan strategi mengajar yang kurang tepat, atau karena faktor lain. 
Pada dasarnya kesulitan belajar siswa dipengaruhi oleh faktor yang berasal dari dalam diri (intern) dan faktor yang berasal dari luar dirinya (ekstern). Di antara faktor yang berasal dari dalam diri tersebut adalah kondisi fisik, kemauan belajar, minat, bakat, inteligensi dan sebagainya. Sedangkan faktor yang berasal dari luar diri siswa di antaranya adalah guru, materi, media pengajaran, dan strategi yang digunakan guru dalam mengatasi kesulitan belajar siswa.

Sejalan dengan hal di atas, masalah-masalah yang berhubungan dengan upaya mengatasi kesulitan belajar siswa adalah kondisi fisik, kemauan belajar, minat, bakat, inteligensi, guru, materi, media dan strategi yang digunakan guru mengatasi kesulitan belajar siswa. Sejalan dengan hal tersebut penulis tertarik untuk membahas Strategi Pengawas Sekolah dalam Membantu Guru Mengatasi Kesulitan Belajar Geografi di Kelas XI SMA Swasta Kesuma Indah T.P. 2017/2018.

Berdasarkan latar belakang masalah yang diuraikan di atas, maka masalah yang dibahas dalam penelitian ini dapat dirumuskan sebagai berikut.

1. Bagaimanakah strategi guru dalam mengatasi kesulitan belajar siswa pada mata pelajaran Geografi di SMA Swasta Kesuma Indah T.P. 2017/2018?

2. Apa saja masalah yang dihadapi guru dalam mengatasi kesulitan belajar siswa pada mata pelajaran Geografi di Kelas XI SMA Swasta Kesuma Indah dan bagaimana upaya menanggulanginya 2017/2018?

\section{Tujuan dan Kegunaan Penelitian 1. Tujuan Penelitian}

Tujuan penelitian dan pembahasan skripsi ini adalah untuk mengetahui:

a. Untuk mengetahui strategi pengawas sekolah dalam membantu guru mengatasi kesulitan belajar siswa pada mata pelajaran Geografi di Kelas XI SMA Swasta Kesuma Indah 2017/2018.

b. Untuk mengetahui masalah yang dihadapi dalam mengatasi kesulitan belajar siswa pada mata pelajaran Geografi di Kelas XI SMA Swasta Kesuma Indah T.P. 2017/2018 dan upaya menanggulanginya.

\section{PENGERTIAN DAN JENIS-JENIS KESULITAN BELAJAR SISWA}

Kesulitan belajar siswa antara lain tampak dari hambatan-hambatan tertentu untuk mencapai hasil belajar yang maksimal, dan penyebabnya dapat bersifat psikologis, sosiologis, maupun fisiologis, sehingga pada akhirnya dapat menyebabkan prestasi belajar yang dicapainya berada di bawah semestinya.

Menurut Hasan Rachjadi (1997: 21) kesulitan belajar adalah apabila murid mengalami kegagalan tertentu dalam mencapai tujuan-tujuan belajarnya. Kegagalan itu meliputi tidak dapat mencapai nilai enam, under achiever, slow leaner dan repeater.

Learning Disorder atau kekacauan belajar adalah "keadaan dimana proses belajar seseorang terganggu karena timbulnya respons yang bertentangan". Pada dasarnya, yang mengalami kekacauan belajar, potensi dasarnya tidak dirugikan, akan tetapi belajarnya terganggu atau terhambat oleh adanya respons-respons yang bertentangan, sehingga hasil belajar yang dicapainya lebih rendah dari potensi yang dimilikinya. Learning Disfunction merupakan gejala dimana proses belajar yang dilakukan siswa tidak berfungsi dengan baik, meskipun sebenarnya siswa tersebut tidak menunjukkan adanya subnormalitas mental, gangguan alat dria, atau gangguan psikologis lainnya. Under Achiever mengacu kepada siswa yang sesungguhnya memiliki tingkat potensi intelektual yang tergolong di atas normal, tetapi prestasi belajarnya tergolong rendah. Contoh: siswa yang telah dites kecerdasannya dan menunjukkan tingkat kecerdasan tergolong sangat unggul (IQ = $130-140$ ), namun prestasi belajarnya biasa-biasa saja atau malah sangat rendah. Slow Learner atau lambat belajar adalah siswa yang lambat dalam proses belajar, sehingga ia membutuhkan waktu yang lebih lama dibandingkan sekelompok siswa lain yang memiliki taraf potensi intelektual yang sama. Learning Disabilities atau ketidakmampuan belajar mengacu pada gejala dimana siswa tidak mampu belajar atau menghindari belajar, sehingga hasil belajar di bawah potensi intelektualnya.

Kesulitan belajar merupakan masalah yang cukup kompleks dan kadang-kadang sulit untuk 
mencari penyelesaiannya. Kesulitan belajar banyak ditemukan pada siswa usia sekolah. Pada masa ini siswa tidak hanya belajar menghitung, membaca, atau menghafal pengetahuan umum, tapi juga belajar tentang tanggung jawab, skala nilai moral, skala nilai prioritas dalam kegiatannya. Karena itu siswa membutuhkan bimbingan belajar dari guru.

Menurut Dewa Ketut Sukardi (1993:21) bimbingan adalah suatu proses bantuan yang diberikan kepada seseorang dengan memperkembangkan potensi-potensi yang dimiliki, mengenali dirinya sendiri, mengatasi persoalan-persoalan sehingga mereka dapat menentukan sendiri jalan hidup secara bertanggung jawab tanpa tergantung pada orang lain.

Dari uraian di atas dapat disimpulkan bahwa yang dimaksudkan dengan kesulitan belajar adalah hambatan-hambatan tertentu yang dihadapi siswa untuk mencapai hasil belajar yang maksimal, yang terdiri dari (1) kekacauan belajar, (2) proses belajar yang dilakukan siswa tidak berfungsi dengan baik, (3) siswa memiliki kemampuan intelektual tinggi tetapi hasil belajarnya rendah, (4) lambat belajar dan ketidakmampuan belajar.

\section{METODOLOGI PENELITIAN}

Penelitian ini digolongkan kepada penelitian tindakan. Arikunto (2006:90) menjelaskan bahwa "penelitian tindakan adalah penelitian tentang hal-hal yang terjadi di masyarakat atau kelompok sasaran, dan hasilnya dapat langsung dikenakan pada masyarakat yang bersangkutan". Ciri atau karakteristik utama dalam penelitian tindakan adalah adanya partisipasi dan kolaborasi antara peneliti dengan anggota kelompok sasaran.

Penelitian tindakan Sekolah ini dirancang dengan langkah-langkah yang meliputi studi pendahuluan, perencanaan tindakan, pelaksanaan tindakan, observasi dan refleksi. Penelitian Tindakan Kelas ini dilaksanakan di Kelas XI SMA Swasta Kesuma Indah Padangsidimpuan. Teknik pengumpulan data yang digunakan dalam penelitian ini adalah tes unjuk kerja dan observasi. Analisis data dilaksanakan dengan cara kualitatif dan kuantitatif.
HASIL PENELITIAN DAN PEMBAHASAN Kondisi Awal

Kondisi awal menunjukkan ada beberapa siswa yang mengalami kesulitan belajar pada mata pelajaran Geografi di SMA Swasta Kesuma Indah Padangsidimpuan.

Kesulitan belajar tersebut di antaranya adalah berkaitan dengan kelambatan dan kekacauan belajar. Misalnya ada siswa yang pandai pada mata pelajaran Geografi tetapi kesulitan membaca peta buta, hasil belajar siswa tgidak sesuai dengan yang diharapkan dan sebagainya. Kondisi inilah yang menjadi acuan untuk melaksanakan tindakan berikutnya.

\section{Siklus 1}

Langkah pertama yang dilakukan pada siklus 1 adalah melakukan pertemuan dengan guru Geografi untuk membahas tentang langkahlangkah yang akan dilakukan dalam mengatasi kesulitan belajar siswa. Pengawas memberikan pengarahan tentang cara-cara yang akan dilakukan dalam menanggulangi kesulitan belajar siswa.

Langkah kedua pengawas membantu guru melakukan identifikasi kasus terhadap kesulitan belajar yang dihadapi siswa, Selanjutnya guru menandai siswa yang diperkirakan mengalami kesulitan belajar. Dengan menandai siswa yang mengalami kesulitan belajar tersebut guru dapat melakukan pendekatan individual untuk membantu siswa mengatasi kesulitan belajar yang dihadapinya.

Langkah ketiga melakukan lokalisasi jenis dan sifat kesulitan agar lebih mudah untuk membantu siswa mengatasi kesulitan belajar yang dihadapinya, karena setelah jenis dan sifat kesulitan belajar diketahui maka dapat dicari langkah-langkah penanggulangan yang relevan.

Langkah keempat berusaha untuk menemukan faktor penyebab kesulitan belajar yang dihadapi siswa, baik yang bersifat internal maupun yang bersifat eksternal. Dalam hal ini guru berupaya untuk melakukan pendekatan individual dan menggali keterangan dari siswa tentang masalah-masalah yang dihadapinya sehingga ia mengalami kesulitan dalam belajar.

Berdasarkan pengamatan penulis langkah-langkah yang dilaksanakan tersebut dapat mengurangi kesulitan belajar siswa. Hal ini ditandai dengan meningkatnya keaktifan dan hasil belajar siswa. 
Siklus 2

Kesulitan belajar berpengaruh terhadap perolehan nilai siswa. Untuk itu langkah pertama yang dilakukan pengawas pada siklus 2 adalah membantu guru meneliti nilai ulangan yang tercantum dalam record akademik, kemudian dibandingkan dengan nilai rata-rata kelas atau dengan criteria tingkat penguasaan minimal kompetensi yang dituntut. Dengan melakukan analisis terhadap hasil ujian setiap siswa, dan membandingkannya dengan nilai rata-rata kelas, akan diketahui apakah nilai yang diperoleh siswa berada di atas, sama dengan atau di bawah nilai rata-rata kelas.

Jika siswa memperoleh nilai di bawah nilai rata-rata kelas, maka akan memberikan remedial kepada siswa. Di antaranya adalah dengan cara memberikan modul atau tugas-tugas yang harus diselesaikan siswa dalam jangka waktu tertentu.

Upaya mengatasi kesulitan belajar siswa diawali dengan perkiraan alternatif pertolongan yang akan diberikan kepada siswa yang mengalami kesulitan belajar. Guru membuat coretan-coretan tentang masalah kesulitan belajar yang dihadapi siswa dan kemungkinankemungkinan upaya mengatasinya. Di antara alternatif penyembuhan kesulitan belajar yang mereka laksanakan adalah bimbingan individual, memberikan remedial, penerapan tutor sebaya, melakukan kerja sama dengan wali kelas dan orangtua, serta memberikan ganjaran dan hukuman kepada siswa.

Penanggulangan kesulitan belajar siswa selanjutnya dilakukan dengan bekerjasa sama dengan wali kelas dan kadang-kadang dengan Kepala Sekolah serta orangtua siswa. Bentuk kerja sama yang dilaksanakan dengan Wali kelas dalam mengatasi kesulitan belajar siswa, di antaranya adalah melaporkan kepada wali kelas bahwa ada siswanya yang mengalami kesulitan belajar. Biasanya siswa yang dilaporkan tersebut adalah siswa yang kesulitan belajarnya tergolong paling parah di antara kawan-kawannya. Wali kelas memanggil anak dan menasehati, jika tidak berhasil orangtuanya dipanggil agar memberikan perhatian kepada anak dan membantu anak mengatasi kesulitan belajar yang dihadapinya.

\section{Masalah yang Dihadapi dan Upaya Menanggulanginya}

Berdasarkan hasil penelitian, maka masalahmasalah yang dihadapi dalam menanggulangi kesulitan belajar siswa berasal dari dalam dan luar diri siswa. Masalah yang berasal dari diri siswa di antaranya adalah siswa sulit diatur. Misalnya ketika guru ingin membantu mengatasi kesulitan belajarnya, siswa justru melakukan penolakan, yaitu tidak menuruti saran-saran yang disampaikan guru. Untuk menanggulangi masalah tersebut, maka guru melakukan pendekatan individual kepada siswa, dan memperlakukan siswa sebagai teman agar dapat menerima saran-saran yang disampaikan guru.

Kurangnya peran aktif orangtua dalam membantu mengatasi kesulitan belajar siswa merupakan salah satu masalah yang dihadapi dalam mengatasi kesulitan belajar siswa. Untuk menanggulangi Masalah tersebut guru berusaha menjalin komunikasi dan menyampaikan kesulitan belajar yang dihadapi siswa kepada orangtuanya. Selanjutnya pihak sekolah meminta orangtua untuk membantu mengatasi kesulitan belajar siswa.

\section{PEMBAHASAN HASIL PENELITIAN}

Hasil penelitian menunjukkan ada beberapa kesulitan belajar yang dihadapi siswa pada mata pelajaran Geografi di SMA Swasta Kesuma Indah Padangsidimpuan, di antaranya siswa yang sesungguhnya memiliki tingkat potensi intelektual yang tergolong di atas normal, tetapi prestasi belajarnya tergolong rendah, lambat belajar dan ketidak mampuan belajar.

Menurut analisa penulis kesulitan-kesulitan belajar yang disebutkan di atas, pada dasarnya masih dalam taraf toleransi, artinya jika guru melakukan strategi yang tepat kesulitan belajar tersebut masih dapat ditanggulangi. Apalagi jika dibantu oleh wali kelas, orangtua siswa dan guru bidang studi yang lain. Karena itu penerapan strategi yang tepat dalam membantu mengatasi kesulitan belajar siswa merupakan hal yang penting agar siswa mampu mengatasi kesulitan belajar yang dihadapinya.

\section{KESIMPULAN}

Kesulitan belajar yang dilami siswa pada mata pelajaran Geografi di Kelas XI SMA Swasta Kesuma Indah di antaranya proses belajar yang dilakukan siswa tidak berfungsi dengan baik, siswa yang sesungguhnya memiliki tingkat potensi intelektual yang tergolong di atas normal, tetapi prestasi belajarnya tergolong rendah.

Strategi yang dilakukan guru untuk mengatasi kesaulitan belajar adalah identifikasi 
kasus kesulitan belajar, menandai siswa yang mengalami kesulitan belajar, meaalakukan lokalisasi jenis dan sifat kesulitan, berusaha menemukan faktor penyebab kesulitan belajar yang dihadapi siswa, meneliti hasil ulangan dan membandingkannya dengan nilai rata-rata kelas, melakukan obsservasi terhadap prilaku belajar siswa, merencanakan alternatif penyembuhan dan melaksanakan penyembuhan.

Masalah-masalah yang yang dihadapi guru dalam mengatasi kesulitan belajar siswa adalah masalah yang berasal dari dalam diri siswa, seperti siswa sulit diatur dan masalah dari luar diri siswa kurangnya peran aktif orangtua. Upaya yang dilakukan untuk menanggulangi masalah tersebut adalah melakukan pendekatan individual, memberikan remedial kepada siswa, berusaha memanfaatkan fasilitas yang ada secara optimal, dan menjalin komunikasi dengan orangtua untuk membantu mengatasi kesulitan belajar siswa.

DAFTAR RUJUKAN

Djamarah, Syaiful Bahri dan Aswan Zain. Strategi Belajar Mengajar. Jakartra: Rineka Cipta, 2006.

Djumhur I. dan Moh. Surya. Bimbingan dan Penyuluhan di Sekolah, Bandung: CV Ilmu, 1987.

Halim, A. Ridwan. Tindak Pidana Pendidikan Suatu Tinjauan Edukatif. Jakarta: Ghalia Indonesia, 1985

Imron, Ali. Pembinaan Guru di Indonesia. Jakarta: Pustaka Jaya, 1995.

Moleong, Lexy J. Metodologi Penelitian Kualitatif. Bandung: Remaja Rosda Karya, 2004

Sardiman, Interaksi Belajar Mengajar, Jakarta: Rineka Cipta, 2002.

Soekartawi, Meningkatkan Efektifitas Mengajar. Jakarta: Radar Jaya, 1995.

Sukardi, Dewa Ketut, Dasar-Dasar Bimbingan dan Penyuluhan di Sekolah, Surabaya: Usaha Nasional, 1993.

Suwatno, Mengatasi Kesulitan Kelajar Mmelalui Kklinik Pembelajaran, Disampaikan pada Workshop Evaluasi dan Pengembangan Teaching Klinik bagi Dosen Fakultas Ekonomi Universitas Negeri Padang,Pada tanggal, 21 sd. 26 Januari 2008, Padang: Fakultas Ekonomi Universitas Negeri Padang, 2008.

Usman, Moh. Uzer. Menjadi Guru Profesional. Bandung: Remaja Rosda Karya, 1995. 